\title{
Youtube for Teaching Listening in English Language: the Benefits in Experts' Views
}

\author{
I Putu Bayu Pasek Hendrayasa ${ }^{1 *}$ (D) \\ ${ }^{1}$ Ganesha University of Education, Singaraja, Indonesia \\ *Corresponding author: iputubayupasekhendrayasa@undiksha.ac.id
}

\begin{abstract}
Abstrak
Beberapa siswa Indonesia mengungkapkan bahwa mereka menemukan kesulitan dalam belajar mendengarkan karena mendengarkan hanya dapat dilakukan dalam satu kesempatan tanpa dapat mengulanginya. Tujuan dari penelitian ini adalah untuk menganalisis pengaruh penggunaan video YouTube dalam pengajaran mendengarkan dengan mengevaluasi hasil penelitian sebelumnya dalam temuan dan memeriksa beberapa referensi tertulis yang meliputi teori, keyakinan, temuan penelitian, dan sumber lain yang terkait dengan dampak video YouTube. Penelitian ini menggunakan penelitian kepustakaan sebagai teknik pengumpulan data yang menggunakan sumber dari beberapa dokumentasi. Sumber data diperoleh dari sumber tertulis yang terkait dengan penggunaan video YouTube dalam pengajaran mendengarkan. Hasil penelitian menunjukkan jumlah siswa terbanyak (54 siswa) yang mengaku YouTube hanya untuk hiburan, sedangkan tiga siswa mengakses YouTube terkait materi pendidikan lainnya. Dapat disimpulkan bahwa YouTube adalah situs web tempat para guru atau siswa dapat mengambil bahan ajar otentik, video hiburan, dan dapat digunakan sebagai sumber belajar. Siswa tampak tertarik dengan kegiatan belajar saat menggunakan YouTube karena video YouTube menarik perhatian mereka. Siswa dapat memperoleh wawasan yang lebih baik tentang pelajaran mata pelajaran dengan bantuan video YouTube yang memberikan dukungan visual.
\end{abstract}

Kata kunci: YouTube, Mengajar, Mendengarkan

\section{Abstract}

Several Indonesian students said that they found difficulties in listening because listening could only be done on one occasion without being repeated. This study aims to analyze the influence of YouTube videos in research related to the results of previous studies in the findings and examine several written references, including theories, beliefs, and research findings related to YouTube videos. This study uses library research as a data collection technique that uses sources from several documentations. Sources of data were obtained from written sources related to YouTube videos in listening to the teaching. The results showed that the highest number of students (54 students) admitted that only YouTube was for entertainment, while three students accessed YouTube related to other educational materials. It can be said that YouTube is a website where teachers or students can take authentic materials, entertainment videos and can be used as learning resources. Students seem interested in learning activities when using YouTube because YouTube videos attract their attention. Students can gain better insight into the subject matter with the help of YouTube videos which provide visual support.

Keywords: YouTube, Teaching, Listening

\section{INTRODUCTION}

Video-based learning is not a new theory in language teaching methodology, many studies have focusing on the effectiveness of using videos as media in foreign language teaching are still highly conducted by language teaching experts (Bajrami \& Ismaili, 2016; Kamelia, 2019; Megawati \& Utami, 2020). English plays an important role in many aspects of human life; one of them is in educational aspect (Hajri et al., 2018; Tanihardjo, 2016). Since English has become a meaningful subject of language learning in Indonesia educational institutions (Djami \& Kuswandono, 2020; Hanifa, 2018; Khotimah et al., 2019). English has been taught for many years from primary school to higher education level. The purposes of learning English are beneficial for everyone who was adapting to the global era and not only for those who major in English (Gunawan et al., 2019; Khotimah et al., 2019; Zein et al., 2020). Videos have been helpful material for teachers to enhance student's language learning skills (Bajrami \& Ismaili, 2016; Megawati \& Utami, 2020; Putri et al., 2020). Furthermore,

$\begin{array}{lll}\text { History: } & & \text { Publisher: Undiksha Press } \\ \text { Received } & \text { : June 15, } 2021 & \text { Licensed: This work is licensed under } \\ \text { Revised } & \text { : June 20, 2021 } & \text { a Creative Commons Attribution 3.0 License } \\ \text { Accepted } & \text { : October 17, 2021 } & \text { C. (†) O) } \\ \text { Published } & \text { : November 25, 2021 }\end{array}$


encouraging students' cognitive development is proved to be efficient using videos. videos enable language learners to achieve vocabulary and grammar, encourage pronunciation ability, and increase their language skills such as reading, writing, speaking, and listening.

Students receive information while learning a language through receptive skills; one of them is listening (Alilateh \& Widyantoro, 2019; Gilakjani \& Sabouri, 2017). Listening skills are the most important skills that must be prioritized from other language skills such as reading, writing, and speaking (Alodwan \& Almosa, 2018; Atiyah \& Izzah, 2019). Listening is an important skill for a student's language development. Listening as a process of receiving what is heard and analyzing in into verbal units where meaning is then applied (Sah \& Shah, 2020; Saraswaty, 2018), The main means of hearing and understanding information from an idea put forth by someone. Thus, English foreign language students are supposed to have good ability in listening skills. Listening takes up 40-50\% rather than other skills on communication (Rizkan, et al., 2019). However English foreign language students find listening very difficult to achieve. Some of Indonesian students revealed that they found difficulties in learning listening because listening can only be done in one shot without being able to repeat it (Hanifa, 2018; Kurniawati, 2016). To decrease this problem, the teacher should find or use teaching media to facilitate the teaching and learning of listening (Chien et al., 2020; Perez et al., 2013). As explained above, YouTube video is one of the alternative tools to be used in language teaching which provides audio-visual information. It offers fun and fast access to instruction, culture-based videos, and language from all over the world.

Technology also plays an important role in this global era in which technology can be used for many aspects of daily life (Phelps et al., 2021; Raja \& Nagasubramani, 2018). Nowadays, the use of internet also increase very dramatically (Juwandi \& Widyana, 2019; Tempola et al., 2020). The beneficial that technology offers for learners are many online materials, like learning websites, and a lot of incredible information sources. There are many various of program and application based on internet or web, one of them is YouTube (Fachriyah, 2020; Mahasneh et al., 2021).YouTube is considered a source of online material that can play a key role in the teaching and learning field. In addition, YouTube websites can provide teachers and students with everyday videos and authentic situations that may help the students improve their understanding and performance in English language lessons (Khatri et al., 2020; Selvi et al., 2020). Learners can gain positive indicators when they watch authentic and real-life clips. YouTube is one of online learning media which contain several kind of video made by creator who become its content creator. Furthermore, YouTube videos give the students chance to memorize the lesson more easily. Some previous researcher also had been examined the effect of using YouTube video in teaching listening skill (Ho \& Tai, 2020; Saed et al., 2021). The result of the research showed that there was a positive effect of using YouTube video in improving students' listening ability. By utilizing some previous studies, this research is aimed to review the effect of the use of YouTube video in enhancing students' listening skill.

\section{MATERIALS AND METHODS}

This research used library research; a data collection technique that uses sources from several documentations. Library research is a research that carried out by collecting information and data from the various materials in the library such as books, similar results of previous research, articles, notes, and various journals related to the problem to be solved. In this case, the data sources are acquired from written resources related to the use of YouTube videos in teaching listening. The writer collected all information from the literature and studied the researcher's point of view related to the discussed topic. Then, the writer concluded a significant point which later produces the solution for the problems in teaching listening. 


\section{RESULTS AND DISCUSSION}

\section{Result}

A survey was conducted to see students' points of view related to the use of YouTube videos in learning English at Northern Taiwan to 69 university students. The students were in sophomore year that enrolled in English class (Kelsen, 2016). From students, $92 \%$ of male students and $84 \%$ of female students had access over the internet connection and acknowledge that they were regularly accessed or connected to this social media. However, students rarely used YouTube to learn English before YouTube being implemented in the class. The highest number of students (54 students) admitted that YouTube is entertainment purposes only, while three of the students accessed YouTube related to other educational materials. The first and second-semester students were introduced to YouTube. After experiencing the learning methodology by using YouTube, it was discovered from the survey that the frequency of accessing YouTube outside of the classroom increased. Even, the students started taking advantage of YouTube in learning English. Of 69 students, 30 students thought that YouTube is interesting. Moreover, from the 69 students, 32 students found the subjects learned are relevant to YouTube videos. Furthermore, 21 and 24 students stated that they felt motivated to learn English inside and outside the classroom when using YouTube.

The results of her research are the students thought that YouTube assists them to improve their English proficiency especially in speaking and listening. It also found that since the students can access YouTube inside and outside the classroom, students had better learning. there was a positive result of YouTube videos in listening class. Moreover, the students felt that their knowledge increase because they can repeat the videos (learning materials) on YouTube. Students admitted that they can easily find many videos that can be used as a source to improve their listening comprehension. Moreover, Previous research found out that the students' listening comprehension improved significantly because the use of video (Kim, 2017). The study aimed to find out the tendency in using social media as learning resources that exist among students (Liu, 2010). The 212 students of the University of Houston were involved in this investigation as the sample. The results showed that a high number of students used YouTube as their learning resources. It showed from the percentage that $70 \%$ of students were accessing YouTube while 30\% of the students using podcasts. It also revealed that YouTube gives easy access and unlimited information also an authentic resource to the students. Through YouTube videos, helps the student enhance their analytical skill along with other skills in the learning process.

Students tend to be directed by the teacher to watch, plan, and practice before they getting tasks from their teacher. He wrote that teachers can use videos Karaoke taken from YouTube to enhance their listening skills as well as other skills like vocabulary, contraction, speed, and tempo of speech. listening is facilitated by the wide range of language aspects. YouTube provides students' a visual media content that they familiar with within an educational context. The study result is presented steps and procedures to improve students' motivation and participation in the CLIL context. The study also shows the way the audiovisual video from YouTube can be used to teach low-level learners the other subjects through English. The video with subtitles is often getting the students concentration because most students usually concentrate largely on the written word, by the loss of many visual and aural representation of the message. This study also indicated that the authentic material as well as the activities and tasks for teaching using video is important to choose carefully. The findings show that YouTube video integration can effectively improve student's learning and increase their involvement (Silviyanti's, 2014). Watching YouTube videos are considered a more functional activity than the traditional method. These findings indicate that YouTube videos provide high learning and are most effective at enhancing the students' educational knowledge as well as skills. 


\section{Discussion}

From the result, it shows that YouTube has improved students' listening ability. student' listening and speaking ability improved after using YouTube. In addition, their knowledge of the subject learned is developed. The learning process using YouTube videos, students' analytical skills are developed among the other skills (Lapitan et al., 2021; Liu, 2010). Furthermore, Liu explained that this happens because the authentic resources and unlimited information are providing by YouTube. The students' perception that YouTube motivated them to learn listening (Hussaeni et al., 2020; Kelsen, 2016). Besides, they thought that listening by using YouTube made learning more interesting (Alwehaibi, 2015; Fachriyah, 2020). YouTube application in teaching listening in the classroom can make students are motivated and interested in learning listening.

YouTube enabled the teacher to create activity in improving students' listening ability as well as helping them identifying vocabulary, contraction, speed, and tempo of speech (Khalid \& Muhammad, 2012; Khatri et al., 2020). YouTube is a good site to be used in enhancing students' listening comprehension. It was discovered that YouTube supply both visual and audio to the learners which gave the students the opportunity to figure out the speech or words that they heard while learning the subject content as well as improving their language ability (Saed et al., 2021; Selvi et al., 2020). The study result shows that students' motivation and participation can be enhancing when using YouTube as authentic materials. Besides that, the activities and tasks for teaching using videos should be chosen carefully.

Students' attitudes towards YouTube videos integration with the students' improvement in listening. It was found that the student's motivation and participation in class activity had increased. Thus, YouTube videos obviously have benefits in helping students to improve their ling comprehension ability. YouTube are affecting students listening proficiency and also impacts on the other skills such as speaking and vocabulary (Fachriyah, 2020; Khalid \& Muhammad, 2012; Khatri et al., 2020). There are certain elements like audio-visual aid and video-text contents in YouTube which enable learners understand well. Aside from the performance aspects, students' attitudes towards the use of YouTube point to positives influences. By using YouTube, students were motivated, interested, active, productive, and enjoyed the listening activity. In consequence, YouTube videos are seemed to be able to provide the learning materials, especially for teaching listening to the students.

\section{CONCLUSION}

Students seemed interested in learning activities when using YouTube because YouTube videos attract their attention. Students could get a better insight into the subject lesson with the help of YouTube videos which provide visual support. Furthermore, YouTube videos gain students' knowledge as well as listening skills because it makes the classroom situation when learning more enjoyable, motivating, interesting, cooperative, creative, and productive. By using YouTube videos, they should be active and productive during the lesson.

\section{REFERENCES}

Alilateh, A., \& Widyantoro, A. (2019). The effectiveness of using multiple intelligence activities in listening comprehension and improving students' interest. LingTera, 6(2), 111-118. https://doi.org/10.21831/lt.v6i2.10625.

Alodwan, T., \& Almosa, M. (2018). The Effect of a Computer Program Based on Analysis, Design, Development, Implementation and Evaluation (ADDIE) in Improving Ninth Graders' Listening and Reading Comprehension Skills in English in Jordan. English Language Teaching, 11(4), 43. https://doi.org/10.5539/elt.v11n4p43. 
Alwehaibi, H. O. (2015). The Impact Of Using YouTube In EFL Classroom On Enhancing EFL Students' Content Learning. Journal of College Teaching \& Learning, 12(2), 121126. https://doi.org/10.19030/tlc.v12i2.9182.

Atiyah, F., \& Izzah, L. (2019). A Comparative Study on the Effectiveness of Using Direct and Audiovisual Methods for Enhancing Students Listening Comprehension. English Language in Focus (ELIF), 2(1), 9-16.

Bajrami, L., \& Ismaili, M. (2016). The Role of Video Materials in EFL Classrooms. Procedia - Social and Behavioral Sciences, 232(April), 502-506. https://doi.org/10.1016/j.sbspro.2016.10.068.

Chien, S.-Y., Hwang, G.-J., \& Jong, M. S.-Y. (2020). Effects of peer assessment within the context of spherical video-based virtual reality on EFL students' English-Speaking performance and learning perceptions. Computers \& Education, 146. https://doi.org/10.1016/j.compedu.2019.103751.

Djami, C. B. N., \& Kuswandono, P. (2020). Teachers' Strategies to Implement Higher-Order Thinking Skills in English Instruction. Metathesis: Journal of English Language, Literature, and Teaching, 4(1), 25. https://doi.org/10.31002/metathesis.v4i1.2048.

Fachriyah, E. (2020). Using YouTube to Evaluate and Practice English Skills : A Case Study of Blended Learning. Proceedings of the 1st International Multidisciplinary Conference on Education, Technology, and Engineering (IMCETE 2019), 410(Imcete 2019), 26-29. https://doi.org/10.2991/assehr.k.200303.007.

Gilakjani, A. P., \& Sabouri, N. (2017). The Significance of Listening Comprehension in English Language Teaching. August 2016. https://doi.org/10.17507/tpls.0608.22.

Gunawan, F., Mayasari, R., Muna, W., \& Masruddin, M. (2019). Lecturer's Language Style and Students' Academic Self Efficacy in Higher Education of Indonesia. Arab World English Journal, 10(2), 77-87. https://doi.org/10.24093/awej/vol10no2.7.

Hajri, T., Jufrizal, J., \& Wahyuni, D. (2018). An Analysis of Difficulties In Answering Structure and Written Expression of TOEFL Made by English Students of Universitas Negeri Padang. English Language Teaching, 7(1). https://doi.org/10.24036/jelt.v7i1.8957.

Hanifa, R. (2018). EFL Published Materials: An Evaluation of English Textbooks for Junior High School in Indonesia. Advances in Language and Literary Studies, 9(2), 166. https://doi.org/10.7575/aiac.alls.v.9n.2p.166.

Ho, W. Y. J., \& Tai, K. W. H. (2020). Doing expertise multilingually and multimodally in online English teaching videos. https://doi.org/10.1016/j.system.2020.102340.

Hussaeni, S., Pratama, H., Arifin, R. A., Winda, A., \& Widianingsih, S. (2020). The Use of YouTube as a Learning Tool in Teaching Listening Skill. International Journal of Global Operation Reserch, 1(3), 123-129. https://doi.org/10.47194/ijgor.v1i3.50.

Juwandi, J., \& Widyana, R. (2019). Pengaruh kemandirian belajar terhadap pemanfaatan internet sebagai sumber belajar. JURNAL SPIRITS, 10(1). https://doi.org/10.30738/spirits.v10i1.6536.

Kamelia, K. (2019). Using Video as Media of Teaching in English Language Classroom: Expressing Congratulation and Hopes. Utamax: Journal of Ultimate Research and Trends in Education, 1(1), 34-38. https://doi.org/10.31849/utamax.v1i1.2742.

Kelsen, B. A. (2016). Teaching EFL to the iGeneration: A Survey of Using YouTube as Supplementary Material with College EFL Students in Taiwan. July.

Khalid, A., \& Muhammad, K. (2012). The Use of YouTube in Teaching English Literature The Case of Al-Majma' ah Community College, Al-Majma' ah University ( Case Study ). International Journal of Linguistics, 4(4), 525-551. https://doi.org/10.5296/ijl.v4i4.2930. 
Khatri, P., Singh, S. R., Belani, N. K., Yeong, Y. L., \& Lohan, R. (2020). YouTube as source of information on 2019 novel coronavirus outbreak: a cross sectional study of English and Mandarin content. Travel Medicine and Infectious Disease, 35. https://doi.org/10.1016/j.tmaid.2020.101636.

Khotimah, K., Widiati, U., Mustofa, M., \& Ubaidillah, M. F. (2019). Autonomous English learning: Teachers' and students' perceptions. Indonesian Journal of Applied Linguistics, 9(2). https://doi.org/10.17509/ijal.v9i2.20234.

Kim, H.-S. (2015). Using Authentic Videos to Improve EFL Students' Listening Comprehension. International Journal of Contents, 11(4), 15-24. https://doi.org/10.5392/ijoc.2015.11.4.015.

Kurniawati, D. (2016). The Use of Video to Enhance the Teaching and Learning Process of Listening English for University Students. English Education Journal, 9(2), 276-289. https://doi.org/10.24042/ee-jtbi.v9i2.373.

Lapitan, L. D., Tiangco, C. E., Sumalinog, D. A. G., Sabarillo, N. S., \& Diaz, J. M. (2021). An effective blended online teaching and learning strategy during the COVID-19 pandemic. Education for Chemical Engineers, 35(May 2020), 116-131. https://doi.org/10.1016/j.ece.2021.01.012.

Liu, Y. (2010). Social Media Tools as a Learning Resource. Journal of Educational Technology Development and Exchange, 3(1). https://doi.org/10.18785/jetde.0301.08.

Mahasneh, D., Shoqirat, N., Singh, C., \& Hawks, M. (2021). "From the classroom to Dr. YouTube": nursing students' experiences of learning and teaching styles in Jordan. Teaching and Learning in Nursing, 16(1). https://doi.org/10.1016/j.teln.2020.09.008.

Megawati, \& Utami. (2020). English Learning with Powtoon Animation Video. Journal of Education Technology, 4(2), 110. https://doi.org/10.23887/jet.v4i2.25096.

Padang, U. N. (2019). case of 2 nd Semester Students of English Education Study Program of Ikip- The Effect Of Using Youtube As A Teaching Media On The Students 'Listening Skill ( The. 301(Icla 2018), 286-291.

Perez, M. M., Noortgate, W. Van Den, \& Desmet, P. (2013). Captioned video for L2 listening and vocabulary learning: A meta-analysis. System, 41(3). https://doi.org/10.1016/j.system.2013.07.013.

Phelps, A., Colburn, J., Hodges, M., \& Hodges, M. (2021). A qualitative exploration of technology use among preservice physical education teachers in a secondary methods

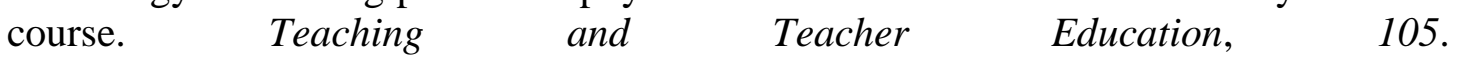
https://doi.org/10.1016/j.tate.2021.103400.

Putri, N. M. L. K., Parmiti, D. P., \& Sudarma, I. K. (2020). Pengembangan Video Pembelajaran dengan Bahasa Isyarat Berbasis Pendidikan Karakter pada Siswa Kelas V di SDLB-B Negeri I Buleleng Tahun Pelajaran 2017/2018. Jurnal EDUTECH Undiksha, 7(2), 8191. https://doi.org/10.23887/jeu.v7i2.23162.

Raja, R., \& Nagasubramani, P. C. (2018). Impact of modern technology in education. Journal of Applied and Advanced Research, 3(S1), 33. https://doi.org/10.21839/jaar.2018.v3is1.165.

Saed, H. A., Haider, A. S., Al-Salman, S., \& Hussein, R. F. (2021). The use of YouTube in developing the speaking skills of Jordanian EFL university students. Heliyon, 7(7). https://doi.org/10.1016/j.heliyon.2021.e07543.

Sah, F. M., \& Shah, P. M. (2020). Teachers 'Beliefs and Practices in Teaching Listening. Creative Education, 11(2), 182-195. https://doi.org/10.4236/ce.2020.112013.

Saraswaty, D. R. (2018). Learners' Difficulties \& Strategies in Listening Comprehension. English Community Journal, 2(1), 139. https://doi.org/10.32502/ecj.v2i1.1003.

Selvi, I., Baydilli, N., \& Akinsal, E. C. (2020). Can YouTube English Videos Be Recommended as an Accurate Source for Learning About Testicular Self-examination? 
Urology, 145. https://doi.org/10.1016/j.urology.2020.06.082.

Silviyanti, T. M. (2014). Looking i nto EFL Students' Per ceptions in Listening by Using English Movie Videos on YouTube. Studies In English Language And Education, 1(1), $42-58$.

Tanihardjo, J. (2016). The Analysis of Students' English Competence in the Grammar Section in the Paper-Based TOEFL: A Case Study at English Department in Bunda Mulia University. Journal of English Language \& Culture, 6(1). https://doi.org/10.30813/jelc.v6i1.270.

Tempola, F., Muhammad, M., \& Mubarak, A. (2020). Penggunaan Internet Dikalangan Siswa SD di Kota Ternate: Suatu Survey, Penerapan Algoritma Clustering dan Validasi DBI. Jurnal Teknologi Informasi Dan Ilmu Komputer, 7(6). https://doi.org/10.25126/jtiik.2020722370.

Zein, S., Sukyadi, D., Hamied, F. A., \& Lengkanawati, N. S. (2020). English language education in Indonesia: A review of research (2011-2019). Language Teaching, 53(4), 491-523. https://doi.org/10.1017/S0261444820000208. 